FORUM

Invited article

DOI: http://dx.doi.org/10.1590/So034-759020170307

\section{DYNAMIC CAPABILITIES, CREATIVE ACTION, AND POETICS}

\author{
Capacidades dinâmicas, ação criativa e poética \\ Capacidades dinámicas, acción creativa y poética
}

\begin{abstract}
Research on dynamic capabilities explores how businesses change enables enterprises to remain competitive. However, theory on dynamic capabilities still struggles to capture novelty, the essence of change. This study argues that a full understanding of strategic change requires us to sharpen our focus on real people and experiences; in turn, we must incorporate other faculties, which almost always operate alongside our logical ones, into our theory. We must pay more attention to the "non-rational" sides of ourselves-including, but not limited to, our imaginations, intuitions, attractions, biographies, preferences, and aesthetic faculties and capabilities. We argue that all such faculties, on the one hand, are central to our abilities to comprehend and cope with complexity and, on the other hand, foster novel understandings, potential responses, and social creativity. This study introduces the possibility of an alternative form of inquiry that highlights the role of poetic faculties in strategic behavior and change.
\end{abstract}

KEYWORDS | Dynamic capabilities, creative action, poetics, strategic change, transformation.

\section{RESUMO}

As pesquisas sobre capacidades dinâmicas exploram como as mudanças nas empresas permitem que elas permaneçam competitivas. Entretanto, a teoria sobre capacidades dinâmicas ainda tem dificuldades em captar a novidade, essência da mudança. Este estudo argumenta que uma plena compreensão das mudanças estratégicas exige-nos aguçar nosso foco sobre pessoas e experiências reais; isso, por sua vez, exige que incorporemos em nossa teoria outras faculdades, as quais quase sempre operam em paralelo a nossas faculdades lógicas. Devemos prestar mais atenção aos lados "não racionais" de nós mesmos - inclusive, mas não somente, nossa imaginação, intuições, atrações, biografias, preferências e faculdades e capacidades estéticas. Argumentamos que, por um lado, todas essas faculdades são centrais para nossas habilidades de compreender e lidar com a complexidade e, por outro lado, favorecem novas compreensões, respostas potenciais e criatividade social. Este estudo introduz a possibilidade de uma forma alternativa de investigação que destaca o papel de faculdades poéticas no comportamento e mudança estratégicos.

PALAVRAS-CHAVE / Capacidades dinâmicas, ação criativa, poética, mudança estratégica, transformação.

\section{RESUMEN}

Estudio sobre capacidades dinámicas explora cómo cambios en negocios permiten que las empresas se mantengan competitivas. Sin embargo, la teoría sobre capacidades dinámicas aún lucha por capturar la novedad, la esencia del cambio. Este estudio sostiene que una comprensión plena del cambio estratégico requiere que agudicemos nuestro foco en personas y experiencias reales; por nuestra parte, debemos incorporar otras facultades, que casi siempre operan lado a lado con nuestras lógicas hacia nuestra teoría. Debemos prestar más atención a los lados "no racionales" de nosotros mismos, incluyendo, pero sin limitarnos, a nuestras imaginaciones, intuiciones, atracciones, biografías, preferencias y facultades y capacidades estéticas. Sostenemos que todas dichas facultades, por un lado, son centrales para nuestras habilidades de comprender y lidiar con la complejidad y, por otro lado, fomentar entendimientos de novedades, respuestas potenciales y creatividad social. Este estudio presenta la posibilidad de una forma alternativa de indagación que enfatiza el papel de las facultades poéticas en el comportamiento y cambio estratégicos.

PALABRAS CLAVE / Capacidades dinámicas, acción creativa, poética, cambio estratégico, transformación. 


\section{INTRODUCTION}

The dynamic capabilities (DC) approach to strategy and strategic change is arguably the most active domain of strategy scholarship at present. Developed over the past two decades, the concept offers a promising way of explaining how firms develop and sustain competitive advantage (Teece \& Pisano, 1994). While this highly influential stream of research (Baretto, 2010; Wang \& Ahmed, 2007) has not escaped criticism-for example, for conceptual inconsistencies and the lack of a coherent theoretical foundation (Arendt \& Bromiley, 2007) -it continues to develop, particularly with regard to managerial action (MacLean, Maclntosh, \& Seidl, 2015), as part of what has been termed "dynamic managerial capability” (Helfat \& Martin, 2015; Helfat \& Peteraf, 2009, 2015). While the renewed focus on managerial action will enrich DC research in terms of conceptual sophistication and potential relevance to practicing managers, this study aims to take the debate into yet newer territory. It argues that the focus on the embodied, practicing manager requires us to acknowledge the faculties that take us closer to an understanding of human experience that can be understood just as well, if not better, in terms of art, rather than science. In particular, it aims to highlight the collective creative action at the heart of DC research as a form of social poetics (MacLean \& MacIntosh, 2015; Shotter \& Katz, 1996), rather than a rationally coordinated mechanism (MacIntosh \& MacLean, 1999).

Elsewhere, and following Barney, Ketchen, and Wright (2011), I argue that most of the problems of DC theory to-date can be traced back to (1) a problematic conceptualization of human action, in particular with regard to creativity, and (2) an ambiguous concept of the actor (MacLean et al., 2015). Acknowledging the progress that is being made through links to the "behavioral theory of the firm" (Augier \& Teece, 2007; Cyert \& March, 1963) or through studies of "dynamic managerial capability" (Adner \& Helfat, 2003; Helfat \& Martin, 2015; Helfat et al., 2007; Kor \& Mesko, 2013; Martin, 2011). I suggest that these innovations do not reach far enough, as they do not account for the creative element inherent to much of human actionparticularly to entrepreneurial action, which was so important to Teece's original conceptualization that he has since stressed the "critical role for the entrepreneurial manager in both transforming the enterprise and shaping the ecosystem through sui generis strategic acts that [do not] stem from routines (or algorisms)" (Teece, 2012, p. 1395). This study arises out of a personal sense that we are overlooking obvious sources of guidance and insight when it comes to understanding entrepreneurial action, or what it means to express "strategic acts that do not stem from routines or algorisms," as mentioned above.
To offer an alternative, first, I present the concept of "creative action" (Joas, 1996), which provides a different way of looking at the creativity expressed by managers (and others) creating change. Then, I develop one aspect of this idea, embodied expression, to depict dynamic managerial capability (Helfat \& Peteraf, 2009) as a form of social poetics (Shotter \& Katz, 1996).

Thus, this paper is structured into three main sections. First, I present a brief overview of the conceptualizations of human action in DC theory and explain the concept of creative action. Then, I develop the "embodied expression" dimension of creative action to show how neglected factors, including biography, aesthetics, emotion, intuition, and imagination, point toward the entrepreneur or change-agent as an artist engaging others in a form of social poetics (Shotter \& Katz, 1996). Finally, I conclude by considering what this might mean for the ways in which we research, develop, and teach strategic management.

\section{CREATIVE ACTION IN DYNAMIC CAPABILITIES}

The literature on strategic management literature and DC are characterized by two familiar types of human action: rational and normative (Joas, 1996). The characteristics of both, and a comparison with a third view-creative action-in the context of DC theory, are dealt with in some detail elsewhere (MacLean et al., 2015) and, thus, will not be repeated here.

In short, rational action, characterized by the explicit analysis of ends, means, and conditions in pursuit of some optimum, depicts behavior as instrumental in the pursuit of utility (Hendry, 2000). Normative views of action are primarily concerned with it being guided by group norms, values, beliefs, and other structures, which govern the patterning of social behaviors in the creation and maintenance of sustainability, persistence, belonging, and so on.

However, as argued, for example, by Hodgkinson and Healey (2011), and more broadly by Joas (1996), even refined and sophisticated developments of rational and normative conceptualizations of action are simply not capable of adequately theorizing creativity or understanding how managers "sense and seize" opportunities and threats, which is central to the DC approach (Teece, 2007).

In contrast, the concept of creative action (e.g., Joas, 1990, 1996) draws on pragmatist philosophy to emphasize how actors experience the specific action situation in which they find themselves, and choose particular courses of action in response to the particulars of that situation. This situational view of action is "able to incorporate the creative dimension of human action into its conceptual structure" (Joas, 1996, p. 72). 
Joas' theory of creative action has three main dimensions (see Figure 1)-action is seen as being comprised of three intertwining threads: (1) intentions emerging and evolving in situations, (2) a socially shaped identity, and (3) embodied expression.

\section{Figure 1. Components of creative action}

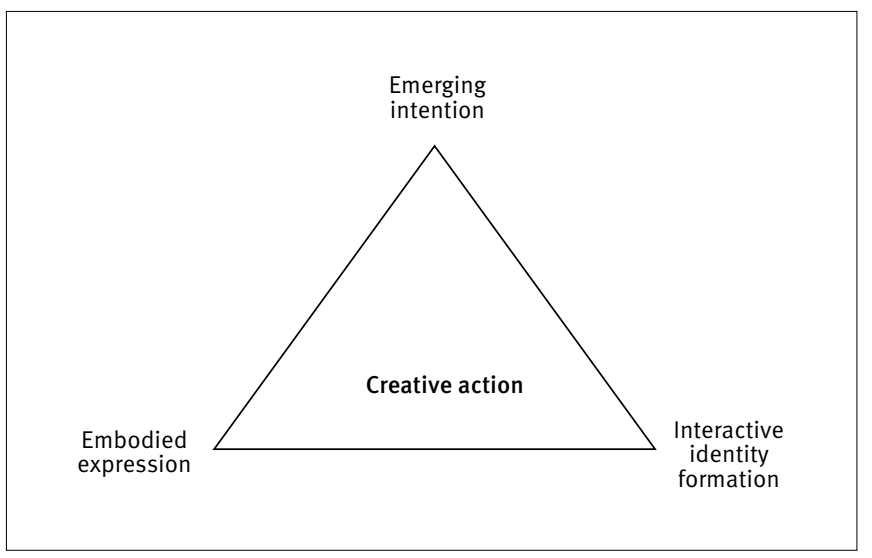

Dealing with the above three dimensions in turn, the first idea of emergent intentions sees both intentionality and outcomes as "emergent," that is, neither formed before action as nor post-rationalized as a consequence of triggered responses. Instead, intentionality is the emerging intellectual awareness of purposeful social action.

Second, socially shaped identity replaces ideas of autonomous (rational) or socially conditioned (normative) individuals, and highlights social interaction and interdependence as primary in the creation of meaning (Berger \& Luckman, 1967; Mead, 1934).

Third, embodied expression focuses on the microphenomena that influence human action-biographical and genetic influences, hopes, feelings, imaginings, intuitions, abilities, power-plays, and so on. The main point here is that the body is an expressive process, not an instrument at the beck and call of intellect, as in the traditional Cartesian view.

A full treatment of creative action, as well as its relation to strategy, DC theory, and other theories of action, is presented elsewhere (MacLean \& Macintosh, 2012, MacLean et al., 2015). In the remainder of this section, the third dimension of creative action, embodied expression, will be covered in a little more detail, as it is this dimension, in particular, that is linked to the idea of poetics.

Ignoring, overlooking, or neglecting the human form in strategy research is at once understandable-as it would introduce simply too much complexity-and, paradoxically, puzzling because we all know from our own experiences that many human stories would be difficult to understand without some understanding of the characters involved and how they tend to behave in a variety of situations. Recognition of the importance of real human bodies in all of their intellectual, sensory, and intuitive variety is key to understanding and, thus, although challenging, to theorizing, which is genuinely meaningful; this is because meaning itself is an embodied experience.

We appear to have a situation in which the role of the human body is a subject of growing interest in organization theory (Hassard, Holliday, \& Willmott, 2000; Strati, 2000), but in which it takes on, at best, various shadow-like appearances in the strategy literature, primarily as an entity that is instrumentally manipulated in the service of intellect and, typically, at a metaphorical level in terms of corporate structure. The body, in all of its fullnessas the location of experience, thought, sensitivity, emotion, intuition, health, biography, and aesthetic awareness-remains as marginalized as the biographies of the unique individual to which it relates. Yet, if we reflect for a moment on the ways in which meaning is created in our lives, we recognize that our body can express actions, feelings, imaginings, and possibilities in ways that rational and normative theories of action simply cannot. For this reason, I argue that the incorporation of the individual human body, as an expressive medium, into the theories of strategic change is, at once, the most radical and challenging offering of a theory of creative action. It is challenging because it points inexorably toward complexity, idiosyncrasy, and a myriad of multidimensional textures that place the generalizable propositions and frameworks of rational analysis beyond our reach. Further, it is radical because it, in turn, forces us not only toward new sciences, like complexity theory, or ideas, like emergence, but possibly beyond science itself, toward other ways of dealing with the often mysterious and paradoxical nature of the embodied human experiences of change.

\section{POETICS AND BARDIC PRACTICE}

If one takes seriously the idea that our experiences of change are emergent, sometimes paradoxical, and not easy to predict or control, then, perhaps, the most obvious recourse in trying to deepen the understanding of them would be complexity theory.

Interested readers are referred to Coveney and Highfield (1996), for a scientifically oriented introduction to complexity theory, or to MacIntosh, MacLean, Stacey, and Griffin (2006), for a review in relation to organization; however, complexity theory contrasts with the view that has underpinned much of our thinking in relation to strategic change.

In contrast to the traditionally dominant (Western) view of the universe as a complicated, closed mechanism rationally 
designed by a supreme intellect, and predictable in its behavior, complexity theory sees the universe as comprising a vast number of "open systems," each of which exchanges energy with its environment and, thus, is not in equilibrium. Such non-equilibrium systems create their own evolving order-they self-organize and can spontaneously transform. Applying this to strategy and organization here, organizations are seen as fluid systems or processes capable of spontaneous, radical, or gradual reconfiguration under the influence of positive and negative feedback, which act on small changes to interconnect patterns, deep structures, or rules, as well as apparently random events (Maclntosh \& MacLean, 1999).

A complexity perspective encourages us to move our language away from the preoccupations of traditional theories of action toward an understanding of action as creative and situated in complex situations. In this sense, rather than action being seen as either rational and deliberate, or normative and emergent (as is often the case in strategy process research (MacLean \& MacIntosh 2012), it is, paradoxically, deliberate and emergent at the same time. By paradox, I mean situations characterized by circumstances in which two apparently incommensurable truths, such as being deliberate and emergent, appear to coexist (Beech, Burns, Caestecker, Maclntosh, \& MacLean, 2004).

Of course, reality is less clear-cut than are debates in strategy journals; intentions emerge in situated interactions between expressive, embodied human beings, as they create meaning together. Plans and strategies can emerge in conversation and emergent strategic patterns can arise when purposeful, politically orientated individuals gather and interact (MacLean \& Maclntosh, 2012). Yet, this seems paradoxical; paradox is a central concept in complexity theory (Prigogine \& Stengers, 1987) and, thus, the idea of paradox-as a central feature of strategic change (MacLean \& MacIntosh, 2015)-is well suited for exploration through complexity theory.

Unfortunately for scientifically minded scholars, traditional science and rationalism do not like paradoxes, which are usually reduced to some sort of tension, difficulty, or problem that must be solved (Beech et al., 2004). However, in the remainder of this study, I follow the suggestion of the Shotter (2011), who argued that our tendency, maybe because of our overly rational educational practices, to cast most of the difficulties we experience in our lives as "problems"-which should have corresponding (optimum) "solutions"-is what prevents us from appropriately understanding and responding to change. While there are undoubtedly benefits to "stepping back" and maintaining an objective stance on occasions, I would suggest that such a response allows for analysis, but not for the change itself. Indeed, conceptualizing the experienced difficulties associated with change as abstract "problems" literally abstracts us from the situation and the people in the situation, often exacerbating the very difficult that is concerning us. Much of what we experience as difficult or challenging is, in fact, "relational"; that is, it might be better tackled, or somehow "resolved," if we engage in creative dialogue together, rather than "representing" our difficulty as an abstract problem that can be solved by purely intellectual means (Shotter, 2011).

However, in my view, Shotter (2011) pointing toward dialogue, while helpful, seems to overlook another area of life in which paradox and challenge are central. Paradox is not only a theme in complexity and emergence, but central to art and, in particular, literature and poetry (Oliver, 2017). In literature, paradox can point to something striking or intriguing, but more nuanced understanding is not usually gained from a cursory glance; for example, in Shakespeare's Hamlet, in the line in Act 3, Scene 4, where Hamlet says to his mother, "I must be cruel, only to be kind," the reader or audience member is struck by the paradox in the terms and drawn into a deeper sense of something meaningful being conveyed in a somewhat mysterious and ambiguous way. It takes an alternative, and perhaps less familiar, faculty to see new possibilities and create viable alternative meanings, which could reveal or create potential new value.

Being able to discern that "something else is going on" in particular episodes of potential change, being able to spot something "off-plan" and perhaps worth pursuing, and spotting a small thread of promise and following it, might be what Chia (2014) is alluding to with his terms "artistic rigor" and "acute empirical sensitivity." In our terms, this ability to "see," and give a compelling voice to, a possible reconfiguration of the present, and a way forward, is exactly why some individuals positively respond to uncertainty. However, it is difficult to approach this from a scientific or purely rational perspective. In extreme cases, it can appear as though something very different from "business as usual" is occurring, as though something new and unexpected is breaking through, glimpsed only by some, as if by magic, and conveyed in terms that can only be described as charismatic or visionary (in the language of today's organizations).

Beech et al. (2004), far from seeing paradox as a problem to be solved, recast it simply as an "invitation to act," resolving (not solving) difficulties by transforming the paradox. In this sense, we are aligning with the idea of paradox in complexity theory, in that it is a process that is simultaneously stable and unstable, and beyond any central control realizing a predetermined form. However, we are also distinguishing our position as different from the scientific view of complexity, enlisting the ideas of creative action to say that, although we are not in control of outcomes, we are not out of control as participants. Emergence includes 
(but is not limited to or by) deliberate participation. Thus, the scientific idea of emergence as "beyond control" is perhaps simply a reflection of the observer's implicit vantage point being external to the system; inside the system or process, as a participant, the issue of control may not even arise (e.g., in a conversation or game of soccer). Indeed, the involvement of certain individuals and their ability to engage others may very well be key to determining what actually emerges in paradoxical situations.

Therefore, in art (and other experiences), emergence is ostensive-known through participation-but by no means outwith our grasp or wholly at the mercy of elements beyond our control, as per the scientific view. Moreover, participation in emergence may not involve following any rigid protocols or "algorisms" (Teece, 2012), but it can still be a creative, deliberate act-a form of expression of the embodied impulses that are, in part, a response to sensory stimuli and, in part, the movement of emerging, biographically influenced ideas and practices.

Abovementioned information is, perhaps, best illustrated by Scruton (1997):

When a painter applies paint to a canvas, he creates a physical object, by purely physical means. This object is composed of areas and lines and paint arranged on a two-dimensional surface. When we look at the painting, we see those areas and lines of paint and also the surface, which contains them. But that is not all we see. We also see a face that looks out at us with smiling eyes. (p. 222)

Combining the threads of this discussion so far leads one to two inter-related implications. On the one hand, emergence is (at best) only partly predictable with regard to the ways in which it unfolds and, on the other hand, the detailed expression of an emergent phenomenon is fashioned through the interaction of the so-called observer and the observed, or creator and the created, in a way that, though not controlled, is not out of our control.

Biologist and complexity theorist Goodwin (1999) has called for the development of a "science of qualities" in response to growing awareness of a participative orientation; he advocated the balancing of quantitative, reductionist science with an approach that is sensitive to the qualities of emergent phenomena as they emerge.

A science would require open recognition of the principle of participation in understanding emergent phenomena and, as part of participative inquiry, would make explicit use of the process of embodied phenomena, such as intuition and feeling. Goodwin (1999) is pointing out that, in social settings, emergence is as much about participation in the creation of meaning as it is about observation, "from the outside" of the development of order. Thus, I would suggest that embodied participation becomes $a$, if not the, fundamental phenomenon. This might require us to rethink our philosophical terrain somewhat; for example, in DC research, we might adopt a view that the best (and perhaps the only) way to fully understand emergent change is through participation in the change itself.

While the above may trouble and challenge us as scientists, it should in no way seem alien to us as human beings. Life is complex; it is replete with paradoxical tensions and, as an experience, it is, by definition, incomplete, partial, and quintessentially dynamic. Our intentions emerge and evolve in interactions with others, as we continually try to negotiate a sense of who we are, what we are doing, whether it is working, and what all of that means (Joas, 1996; MacLean \& MacIntosh, 2012; MacLean et al., 2015). Moreover, while people at work may feel hesitant about describing their endeavors in such terms-for obvious and natural reasons of course-most of us would readily admit to the reality of our lives as ongoing and often challenging social improvisations, perhaps more readily in other domains and communities one step removed from working life, such as personal relationships, sporting encounters, and social lives.

However, with regard to work, the relegation of this reality to the sidelines of managerial discourse and corporate legitimacy is the most baffling and revealing feature of so much of the strategy research. If we fail to recognize ourselves at work as full-bodied, subjective-objective human beings (Powell, 2014), can it be any wonder that we struggle to account for our own behavior? More pointedly, if experience tells us that complex human situations can only be known through participation-that is, from the inside outward-why do we put so much effort into trying to understand them from the outside inward?

Shotter (2011) draws attention to two often opposing forms that knowledge and action can take in organizations: representational (i.e., problem-solving) and expressiveresponsive. In pointing us toward a greater acknowledgement of and engagement with the latter, he calls for what might be styled as a more therapeutic style of involvement, with heightened sensitivity to dialogical practices, noticing small details, listening creatively, paying attention to what is said and how, verbally and non-verbally, in language, and in other expressions of "form." Further, Shotter (2011) calls for less concern for knowing "about” and greater concern for knowing "with," characterized by this heightened sensitivity to often tiny details-perhaps in line with Chia's (2014) call for an "acute empirical sensitivity," such as feelings, "noticings," and intuitions. In my view, this heightened sensitivity and responsiveness are, in fact, located in what we 
might call our artistic or aesthetic faculties, attuned as they are to mystery, paradox, feelings, etc.

In some ways, this is the antithesis of scientific method and linear, dare we say strategic, thinking. This attention to detailto the unusual, to what might, in statistical terms be referred to as "outliers," and the way in which we are guided by our own spontaneous, often intuitive, emotional, and/or imaginative responses-can be so subjective and personal that it might be considered the opposite of rational scientific thinking. Its circular iterative style might equally be said to be the opposite of what the term "strategic thinking" might connote for most. Yet, this tendency to seek deeper significance in contradictions, to embrace paradox, to engage with other people and situations intently and creatively, to give voice confidently and with flair so as to affect others and draw them in to one's world, to disrupt and turn our sense of what might be going on-sharing glimpses of new horizons and inviting others into attractive possible futuresis the engine of social creativity, of, dare we say it, poetry. Far from random, it is highly disciplined, invokes and employs rare capabilities, and craft skills refined through repeated practice. It is distinctive, valuable, difficult to replicate and, as such, is strategic through and through. However, it is not science, but it may be "social poetics" (Shotter \& Katz, 1996).

The above description resonates with contemporary advances in cognitive science and neuroscience. Freedman (2013), reviewing narrative strategy as part of his review of the history of strategy, presents an explanation of "System 1" and "System 2" thinking. The latter is "conscious, explicit, analytical, deliberative, more intellectual and inherently sequential” (p. 603). System 1 thinking, on the other hand, is best illustrated by Freedman's (2013) quote from philosopher Berlin:

(...) a capacity for integrating a vast amalgam of constantly changing, multi-coloured, evanescent, perpetually overlapping data, too many, too swift, too intermingled to be caught and pinned down... to integrate them in this sense is to see the data as elements in a single pattern, with their implications, to see them as symptoms of past and future possibilities, to see them pragmatically, that is in terms of what you and others can or will do to them, or what they can or will do to others and you (...) (p. 613)

This description has a strong similarity with what Shotter (2011) describes as our response to "striking moments" in social poetics, when we are stopped in our tracks and involuntarily seek comparisons and metaphors to help us make sense of what has just arrested us. I would suggest that it is also akin to not only unexpected striking events or resonant surprises, but also to how we might react to a work of art or poetry that affects us.

It is, perhaps, difficult for us to accept that poetics may have a role in organizations and emergent strategy, beyond forming an aesthetic backdrop. Yet, this has undoubtedly been the case in the past. One local example for me is in the tribal clan systems of the Scottish Highlands and Ireland, where "bards" were very prominent figures in clan hierarchies. Odd though it may sound today, a few hundred years ago in Celtic society, poetry was the primary means by which social order and change were created and promulgated. In the social and physical landscapes, in which everyday life was often disrupted by conflict, famine, land-clearance, and migration,“(...) bards kept alive the ancient stories of a race, dramatized new events, and entertained the courts with their long, stylized narratives" (Lehane, 2005, pp. 28-29).

Not everyone could become a bard. Chadwick (2002) points out how disciplined and difficult the process could be, involving highly disciplined and lengthy schooling in poetry, stories, and genealogy, and subject to strict evaluation by masters of the craft. While warriors inevitably occupied the elite positions of the court, the poets were indispensable and, in some cases, became almost as prominent, given their role in creating and sustaining social order as authors and stewards of history and possibility through the stories and art of a people, locating individuals in a vivid and meaningful collective present through highly stylized narrative, poems, songs, and performance arts. They were also seen to have direct access to the ultimate creative powers and would commune with ancestors and gods in order to communicate back to their communities (Shaw, 2016) the need for change when they were required to "step out of the consensus trance reality, observe the psychodynamics of individual or social disease, and then step back in and protest for change" (Maclntosh, 2004, p. 121).

Thus, I am proposing that, in times of strategic change, such as those with which DC thinking is concerned, it is a poetic faculty that allows certain people to "sense and seize" opportunities. If change is a fundamentally creative process, best described as a form of creative action, as laid out earlier in this study, then the socialization of this action into a new coherent whole for those involved is, indeed, a form of social poetics (Shotter \& Katz, 1996).

My argument adds a new dimension, in that I believe that involvement in and leadership of social poetics involves the same faculties involved in poetry. Poïesis-that is, "making," the root of the word "poetry"-involves what Heidegger (1971) termed "bringing forth" into the world, the disclosure or emergence of "being". Thus, in creating new realities for and with themselves and others, today's leaders are, perhaps, expressing the ancient tradition of bardic practice. 
In a modern context, this bardic practice involves some of the abovementioned practices-stepping out of the consensus reality and agitating for change-discerning new emerging possibilities that, through their own participation and ability to engage others, bring novelty into being as a form of "making" that is reminiscent of the following quote from anthropologist Ingold (2010):

Form, to recall Klee's words, is death; form-giving is life. I want to argue that what Klee said of art is true of skilled practice in general, namely that it is a question not of imposing preconceived forms on inert matter but of intervening in the fields of force and currents of material wherein forms are generated. Practitioners, I contend, are wanderers, wayfarers, whose skill lies in their ability to find the grain of the world's becoming and to follow its course while bending it to their evolving purpose. (p. 92)

This paints a picture of the leader not as an externally aloof mechanic or engineer, but as an artistic participant or craftsperson-someone who intervenes in the fluxes of social change and who, with others, teases, bends, and shapes that which is coming forth anyway into a new reality.

\section{CONCLUSIONS AND IMPLICATIONS}

This study has argued that DC in organizations is a form of creative action that involves leaders and others in activities that are essentially poetic. Thus, in leading strategic change, skilled practitioners discern earlier than do most individuals what may be coming into being, and intervene-almost in a form of midwifery practice-to help shape it and bring it into the organization as a new form of being and doing.

As such, practitioners of strategic management are involved in a form of creative action as described above; their intentions emerge and continually evolve in the situation as it takes shape. They engage fully in their own embodied experiences, paying attention to urges, intuitions, imaginings, and emotions alongside logical faculties. Moreover, they interact with others in the situation-listening and responding to small and large details, and using arresting images, stylized prose, compellingly voiced possibilities, and so on-to draw in others as participants in emerging novelty. Thus, they are playing the traditional role of bards, or tribal poets, using art and performance to create new possibilities, narratives, and realities in which others can see themselves. In short, they create new stories that people can tell about themselves and others to help foster coherence, belonging, and collective creative endeavor.

This view of the leader's role in change, while somewhat familiar in historical terms, is in some contrast to the views depicted in DC theory, which typically depicts the manager as an objective and rational manipulator of a somewhat mechanical resource base. Here, I am depicting him/her as more of an artist than a scientist, expressing stylized performances, compelling narratives, and poetic visions to help engage others in the creation of a new reality. Where the rational view of the leader in DC thinking is concerned with optimizing the "functioning" of the organization through reconfiguration, the bardic counterpart is essentially concerned with the creation of new "meaning" through stylized craft and artistic leadership in social interactions (Mead, 1934).

While this view of the change-leader as someone involved in a form of poetics is at an early stage of development and needs further research, I conclude by looking at some of the possible directions for and implications of such a view. First, in terms of further research, the above signals a need to break out of the existing boundaries of our research domains and start working in partnership with individuals not often seen in strategy research-artists, poets, actors, and so on-as they may cast fresh light onto what is actually happening when organizations undergo strategic change. Methodologically, such research is likely to fall at the phenomenological end of the spectrum, with researchers immersed in experiences of strategic change, perhaps engaged as participants in Mode 2 knowledge production processes (MacLean, Maclntosh, \& Grant, 2002), which allow for simultaneous organizational development and inductive theorizing. Attention should focus on relatively unfamiliar areas (as far as strategy research is concerned)-the roles of imagination, poetic forms of language, stylized performance, aesthetics, emotional responses, etc. All of this should be geared toward building a deeper understanding of what actually happens to and through embodied managers and others in the organization during episodes of strategic change. In this sense, such research would align well with Powell's (2014) call to "re-personalize" our field, with a focus on fully embodied people who cannot or do not always disentangle logic, aesthetics, and artistic expression, even at work.

Another implication of the abovementioned information would be that, in our development, education, and training processes, we create more opportunities for the consideration of aesthetics and practice of poetry, drama, and the like. It is, perhaps, time to move beyond the lecture, two-by-two matrices, team-building games, and simulations, and incorporate 
storytelling, poetry, drama, myth, and so on into our education classes. Such developments might not only make our educational practices richer and more fun, but because art seems to access our emotional energies more directly, training in such practices could play a central role in helping to form managers and leaders who are up to the task of creating and engaging others in meaningful change. The point I am trying to make is a very obvious one: if change is a creative process, and creativity is central to the innovation required in many of today's organizations and is the focus of DC theory, perhaps managers and researchers could learn more from people for whom creativity is the fundamental orientation-artists and poets.

\section{REFERENCES}

Adner, R., \& Helfat, C. E. (2003). Corporate effects and dynamic managerial capabilities. Strategic Management Journal, 24(10), 1011-1025. doi:10.1002/smj.331

Arendt, R., \& Bromiley, P. (2009). Assessing the dynamic capabilities view: Spare change, everyone? Strategic Organization, 7(1), 75-90. doi:10.1177/1476127008100132

Augier, M., \& Teece, D. J. (2007). Dynamic capabilities and multinational enterprise: Penrosean insights and omissions. Management International Review, 47(2), 175-192. doi:10.1007/S11575-007-0010-8

Barney, J., Ketchen, Jr., D. J., \& Wright, M. (2011). The future of resource-based theory: Revitalisation or decline. Journal of Management, 37(5), 1299-1315. doi:10.1177/0149206310391805

Barreto, I. (2010). Dynamic capabilities: A review of past research and an agenda for the future. Journal of Management, 36(1), 256-280. doi:10.1177/0149206309350776

Beech, N., Burns, H., Caestecker, L. D., MacIntosh, R., \& MacLean, D. (2004). Paradoxas an invitation to act in problematic change situations. Human Relations, 57(10), 1311-1332. doi:10.1177/0018726704048357

Berger, T., \& Luckman, P. (1967). The social construction of reality. New York, USA: Doubleday.

Chadwick, N. (2002). The Celts. London, UK: Folio.

Chia, R. (2014). Reflections on the distinctiveness of European management scholarship. European Management Journal, 32(5), 683-688. doi:10.1016/j.emj.2014.06.002

Coveney, P., \& Highfield, R. (1995). Frontiers of complexity. London, UK: Faber and Faber Ltd.

Cyert, R. M., \& March, J. G. (1963). A behavioural theory of the firm. Englewood Cliffs, USA: Prentice Hall.

Freedman, L. (2013). Strategy: A history. New York, USA: Oxford University Press.

Goodwin, B. (1999). From control to participation via a science of qualities. Revision, 21(4), 2-10.

Hassard, J., Holliday, R., \& Willmott, H. (Eds.). (2000). Body and organization. London, UK: Sage.
Heidegger, M. (1971). Poetry, language, thought. New York, USA: Harper.

Helfat, C. E., Finkelstein, S., Mitchell, W., Peteraf, M. A., Singh, H., Teece, D. J., \& Winter, S. (2007). Dynamic capabilities: Understanding strategic change in organizations. Malden, USA: Blackwell.

Helfat, C. E., \& Martin, J. A. (2015). Dynamic managerial capabilities: Review and assessment of managerial impact on strategic change. Journal of Management, 41(5), 1281-1312. doi:10.1177/0149206314561301

Helfat, C. E., \& Peteraf, M. A. (2009). Understanding dynamic capabilities: Progress along a development path. Strategic Organization, $7(1)$, 91-102. doi:10.1177/1476127008100133

Helfat, C. E., \& Peteraf, M. A. (2015). Managerial cognitive capabilities and the microfoundations of dynamic capabilities. Strategic Management Journal, 36(6), 831-850. doi:10.1002/smj.2247

Hendry, J. (2000). Strategic decision making, discourse and strategy as social practice. Journal of Management Studies, 37(7), 955-978. doi:10.1111/1467-6486.00212

Hodgkinson, G. P., \& Healey, M. P. (2011). Psychological foundations of dynamic capabilities: Reflexion and reflection in strategic management. Strategic ManagementJournal, 32(13), 1500-1516. doi:10.1002/ smj.964

Ingold, T. (2010). The textility of making. Cambridge Journal of Economics, 34(1), 91-102. doi:10.1093/cje/bepo42

Joas, H. (1990). The creativity of action and the intersubjectivity of reason: Mead's pragmatism and social theory. Transactions, 26(2), 165194 .

Joas, H. (1996). The creativity of action. Cambridge, UK: Polity Press.

Kor, Y. Y., \& Mesko, A. (2013). Dynamic managerial capabilities: Configuration and orchestration of top executives' capabilities and the firm's dominant logic. Strategic Management Journal, 34(2), 233-244. doi:10.1002/smj.2000

Lehane, B. (2005). Early Celtic Christianity. London, UK: Continuum.

Maclntosh, A. (2004). Soil and soul. London, UK: Autumn.

Maclntosh, R., \& MacLean, D. (1999). Conditioned emergence: A dissipative structures approach to transformation. Strategic Management Journal, 20(4), 297-316.

MacIntosh, R., MacLean, D., Stacey, R., \& Griffin, D. (Eds.). (2006). Complexity and organization: Readings and conversations. London, UK: Routledge.

MacLean, D., \& MacIntosh, R. (2012). Strategic change as creative action. International Journal of Strategic Change Management, 4(1), 8097. doi:10.1504/ijscm.2012.045827

MacLean, D., \& MacIntosh, R. (2015). Planning reconsidered: Paradox, poetry and people at the edge of strategy. European Management Journal, 33(2), 72-78. doi:10.1016/j.emj.2015.02.003

MacLean, D., MacIntosh, R., \& Grant, S. (2002). Mode 2 management research. British Journal of Management, 13(3), 189-207. doi:10.1111/1467-8551.00237

MacLean, D., MacIntosh, R., \& Seidl, D. (2015). Rethinking dynamic capabilities from a creative action perspective. Strategic Organization, 13(4), 340-352. doi:10.1177/1476127015593274

Martin, J. A. (2011). Dynamic managerial capabilities and the multibusiness team: The role of episodic teams in executive leadership groups. Organization Science, 22(1), 118-140.

Mead, G. H. (1934). Mind, self and society. Chicago, USA: University of Chicago Press. 
Oliver, B. (2017). The art paradox. Retrieved from http://thoughtleader. co.za/bertolivier/2012/09/17/the-art-paradox/

Powell, T. C. (2014). Strategic management and the person. Strategic Organization, 12(3), 200-207. doi:10.1177/1476127014544093

Prigogine, I. \& Stengers, I. (1984). Order out of chaos: Man's new dialogue with nature. New York, USA: Bantram.

Scruton, R. (1997). Modern philosophy. London, UK: Arrow.

Shaw, M. (2016). Scatterlings. Oregon, USA: White Cloud Press.

Shotter, J. (2011). Getting it: Withness-thinking and the dialogical in practice. New York, USA: Hampton Press.

Shotter, J., \& Katz, A. M. (1996). Articulating a practice from within a practice itself: Establishing formative dialogues by use of a social poetics. Concepts and Transformation, 1(2/3), 213-237. doi:10.1075/ cat.1.2-3.07sho
Strati, A. (2000). Aesthetic theory. In S. Linstead \& H. Hopfl (Eds.), The aesthetics of organization (pp. 13.34). London, UK: Sage.

Teece, D. J. (2007). Explicating dynamic capabilities: The nature and microfoundations of (sustainable) enterprise performance. Strategic Management Journal, 28(13), 1319-1335. doi:10.1002/smj.640

Teece, D. J. (2012). Dynamic capabilities: Routines versus entrepreneurial action. Journal of Management Studies, 49(8), 1395-1401. doi:10.1111/j.1467-6486.2012.01080.x

Teece, D. J., \& Pisano, G. (1994). The dynamic capabilities of firms: An introduction. Industrial and Corporate Change, 3(3), 537-556. doi:10.1093/icc/3.3.537-a

Wang, C. L., \& Ahmed, P. K. (2007). Dynamic capabilities: A review and research agenda. International Journal of Management Reviews, 9(1), 31-51. doi:10.1111/j.1468-2370.2007.00201.x 